\title{
Marlowe's ghost in As You Like It
}

In 1767 Edward Capell recognized Phebe's breathless exclamation in As You Like It 3.5,

Dead Shepheard, now I find thy saw of might,

'Who ever lov'd, that lov'd not at first sight?' $(82-3)^{1}$

as a nod from William Shakespeare to Christopher Marlowe and his Hero and Leander (2.176). ${ }^{2}$ In 1925 Leslie Hotson's discovery of documents related to Marlowe's violent death revived interest in the poet's presence in the play. ${ }^{3}$ In May of the same year Oliver W. F. Lodge identified Touchstone's 'it strikes a man more dead than a great reckoning in a little roome' (3.3.12-13) as a glance at the Coroner's Jury's verdict on Marlowe's homicide and an echo of his 'Infinite riches in a little room' (The Jew of Malta 1.1.37). ${ }^{4}$ Six weeks later Paul Reyher connected Touchstone's remark 'When a man's verses cannot be understood ...' (3.3.10-12) to the suppression of Marlowe's translation of Ovid's Amores. ${ }^{5}$ Ever since the 1926 Cambridge edition of Quiller-Couch and Dover Wilson declared that Lodge's suggestion 'carries conviction' commentators have variously embraced or disputed these inferences. ${ }^{6}$ And there the record of Marlowe sightings in As You Like It has rested until now. ${ }^{7}$

In this chapter I suggest that Christopher Marlowe is not merely an occasional visitor to Shakespeare's anti-pastoral comedy; rather, that in the interval 1599-1600 Shakespeare wrote As You Like It as an emphatic (if discreet) memorial for Marlowe; that Shakespeare created the character of Jaques in the image of Marlowe; and that Shakespeare himself may have taken the part of Jaques in performance. I will suggest that the playwright did so in observance of the seventh anniversary of Marlowe's death in 1593 because the 'seven 
years' mind' for a decedent was regarded as a significant occasion. Towards this end I will show that the text of As You Like It contains more appearances of the word 'seven' and its variants than any other Shakespeare play. ${ }^{8}$ I will also offer evidence that Elizabethans regarded seven as a 'perfect' and holy number, and a cycle of seven years as particularly auspicious. Furthermore, I will propose that in the character of Touchstone Shakespeare sketched a thumbnail of his and Marlowe's sometime collaborator Thomas Nashe (d. 1599-1600). Finally, I will suggest that Shakespeare provides the date of his own arrival at London and his first encounter with the 'University Wits' who dominated the Elizabethan theatrical scene. I will also offer some admittedly speculative inferences regarding Shakespeare's motives.

I recognize that the above may strike the reader as a series of extraordinary conjectures; there is no proof that Shakespeare had even met Marlowe. My reading of the play entails that Shakespeare not only knew Marlowe and recognized his many qualities, faults, and vanities, but valued him as an inspiration and, perhaps, a mentor. If my inferences are correct they will dramatically alter our approach to As You Like It and show it to be a more personal play than we have realized.

I ask only that judgement wait until I have stated my case. ${ }^{9}$

\section{Why 1600 ?}

Christopher Marlowe was killed on 30 May 1593. Scholars date the composition of As You Like It between 30 June 1599 and 4 August $1600 .{ }^{10}$ The date $a$ quo is thought to be set by an exchange between the Clown, Touchstone, and Celia in 1.2:

Clo. The more pittie, that fooles may not speak wisely, what wise men do foolishly.

Cel. By my troth thou saiest true: For, since the littlewit that fooles haue was silenced, the little foolerie that wise men have makes a great shew ... (85-9)

Commentators receive this as a reference to the banning on 1 June 1599 and subsequent burning of satirical books ordered by Bishops Whitgift and Bancroft. ${ }^{11}$ Among other items, the flames consumed works by Nashe and Gabriel Harvey, and Marlowe's translations from Ovid's Amores. 
The date ad quem is fixed by an entry in the Stationers' Register on 4 August 1600 which describes As You Like It as 'to be stayed', that is, the manuscript was to be withheld from printing until further notice. Therefore, the play could have been on stage in May 1600 , the seventh anniversary of Marlowe's death. ${ }^{12}$ But why would the seventh anniversary of one's death be particularly significant - significant enough to move Shakespeare to create a tribute to Marlowe? And given Protestants' rejection of the existence of Purgatory in favour of a judgement to heaven or hell at the moment of death, why commemorate the anniversaries of the dead at all?

\section{On the anniversaries of the dead}

Jacobus de Voragine's The Golden Legend, written circa 1275 and first printed in Genoa circa 1470, became one of the most popular, widely read and most often reprinted early books; during the incunabula period it appeared in more editions than the Bible. William Caxton printed the first Englished Legend in 1483, and it had run through more than a dozen editions before William Shakespeare was born.

In his chapter on the 'The Commemoration of All Souls' de Voragine records that

the church is accustomed to observe three manner days, that is the seventh day, the thirtieth day, and the anniversary ... The trental is kept, which is in three dizains [units of ten], that they [the deceased] may be purged of all such things as they have sinned in the Trinity and breaking of the ten commandments. The anniversary is observed, that they come from the years of calamity and maleurty [unhappiness] unto the years of perdurability. And like as we solemnise every year the feast of a saint to their honour and our profit, right so we observe the anniversary of them that be dead unto their profit and our devotion [my emphasis]. ${ }^{13}$

Pre-Reformation English referred to prayers on the seventh day as a 'week's mind', and those on the thirtieth as a 'month's mind', and those repeated on the anniversary of a death were the 'year's mind'. These obsequies were often bought and paid for by the decedent; one student of wills and legacies left by Englishmen of means in the later Middle Ages discovered that 'merchants preferred a one-, three- or seven-year endowment for anniversary masses, and endowments for 
more than ten years were unusual'. ${ }^{14}$ Clive Burgess, who pored over the wills of late medieval Bristol, discovered a 'plethora of intercessory services commissioned to benefit souls in Purgatory'; some decedents had requested seven years of anniversaries (obits) beginning one year following their death; others, perhaps more mindful of their sins, subscribed for obits in perpetuity. ${ }^{15}$ The Reformation swept away this practice.

Elizabethan Protestants - for whom Purgatory had ceased to exist - no longer believed that post mortem prayers would profit the dead whose souls had immediately gone to heaven or hell. ${ }^{16}$ Marking the anniversary of a loved one's death, perhaps first commended to early Christians by Tertullian (AD 211), remained then as now a rite of respect for the deceased and a salutary exercise for the living. This tradition of annual commemorations, commonplace in early Tudor England, may have lost its standing in the liturgy but remained bright in living memory in Shakespeare's time. But why was the seventh anniversary of a death considered particularly significant?

\section{The perfection and power of seven}

No number - not three nor thirteen - has been so laden with mystical significance in so many cultures and religions over so many centuries as seven. Annemarie Schimmel argues that seven has

fascinated humankind since time immemorial ... The 7 ages of man, cited by Shakespeare, were known in antiquity, and in a pseudoHippocratic book 7 is called the number of cosmic structure ... Solon used the [seven] stellar spheres to divide human life into 7 periods of 10 steps each ... Such ideas were widespread all over the western world, and in the seventeenth century Sir Thomas Browne wrote that every seventh year brings some change in life. [my emphasis]. ${ }^{17}$

Thomas Browne (1605-82) described his book Pseudodoxia Epidemica or Enquiries into very many received tenets and commonly presumed truths (The Epidemic of False Beliefs, sometimes called 'Vulgar Errors') as an effort to correct erroneous 'Received Tennents, And commonly presumed Truths'. In more than 100 chapters and scores of subheads he ruthlessly debunks old wives' tales from the belief that mandrakes howl when cut to the belief that elephants have no joints, that 'a Badger hath the Legs of one 
side shorter than the other', and that 'Jews stinke'. Pseudodoxia was a popular book that ran through six editions between 1646 and 1672 ; it provides a veritable gazetteer of the superstitions and delusions common among Elizabethan and Jacobean men and women of all classes, which ranged from the blatantly racist to the utterly disarming (the rose of Jericho, supposed to flower annually on the day of Christ's nativity, is revealed as a well-intentioned though mischievious monkish canard).

Thumbing through Browne also reveals how deeply the mystical allure of seven was woven into the psyche of Shakespeare's contemporaries. Browne's enumeration of seven's primacy and powers runs to several pages - from the seven days of Creation to the seven descendants of Cain to the Pleiades and man's precarious sixty-third $(7 \times 9=63)$ year - the 'great Climacterical and dangerous year' - to which Browne devotes an entire chapter (chapter XII). Browne endorses the custom by which 'the daies of men are usually cast up by Septenaries [groups of seven years], and every seventh year conceived to carry some altering character with it, either in the temper of the body, mind, or both' (177, my emphasis). So it well might take seven years for the soul to be thoroughly quit of the body.

The principal source of Elizabethans' superstitions about the dominion of seven was the Old Testament, which - excepting the racy bits of the Song of Solomon - they read through once each year. Dr Schimmel epitomized some of the Old Testament appearances of the magic number which Elizabethans encountered annually, beginning with the six days of Creation and Sabbath. Then, in the

seventh generation after Adam there appears Lamech, who lives for 777 years and should be avenged seventy-sevenfold (Gen. 4:24). The 7 steps leading to Solomon's Temple correspond to the 7 stories of the Babylonian temples. Noah's dove stays away for 7 days, and the flood prepares its arrival for 7 days; the Euphrates is divided into 7 brooks. During the sacrificial expiation in ancient Israel, blood was sprinkled 7 times, and a 7-day sacrifice was celebrated when Solomon's temple was inaugurated. (Incidentally, the idea that the soul needs 7 units of time to free itself from the dead body can also be found in other parts of the world ...) [my emphasis]. ${ }^{18}$

This may account for the ritual observation of the 'seven years' mind' as obsequies for the dead. The New Testament is dotted with sevens: Christ on his cross utters seven last words; the Book of 
Revelation, a potpourri of numerology, includes a lamb with seven horns, Christ holding seven stars in his hand, the notorious Seven Seals, letters to seven churches, and the seven trumpets that will sound on Judgement Day.

One assessment of the perfection and holiness of seven - exactly contemporaneous with Shakespeare's writing of Julius Caesar can be found in A New Treatise of the Right Reckoning of Yeares, and Ages of the World, and mens lives (1599) by Robert Pont (1524-1606). ${ }^{19}$ In his preface Pont explains, 'there is a marvelous sympathie of periodes of times, in reckoning by sevens, \& by Sabbatical yeares, and of the manifold mysteries of the number of seaven' (ii). He begins his treatise:

In the beginning (as the Spirite of God recordeth by Moyses) after that the Lord in sixe dayes, had created the Heaven \& Earth, with all the furniture thereof, Hee rested upon the seventh day; Therefore hee blessed it, and hallowed it. This is also repeated in the fourth Commandement, for the perpetuall observation of that day; and because the number of seaven, by that reason is a sacred number, and most meete for al kinde of reckoning. It was ordained also in the lawe, that amongst the people of God, everie seventh yeare should be holden [held] holy ... (7-8, my emphasis)

Clearly, Pont was not just speaking for himself, but for the beliefs of a multitude of his contemporaries.

While we may never be entirely certain of any writer's motives, the time-honoured practice of remembering the anniversaries of a friend's death - coupled with the imputed power of seven may have led Shakespeare to create his elaborate encomium for Christopher Marlowe in 1600, for Raleigh to have responded to Marlowe's 'Passionate Shepherd' in the same year, and for Heminges and Condell to publish the First Folio in 1623 to commemorate the seventh anniversary of Shakespeare's death.

Whatever Shakespeare's motive, his play is brim-full of sevens.

\section{The recurrence of 'seven' in As You Like It}

The rather common word 'seven' and its variants 'seventh', 'seventeen', and 'sennights' appear more often (thirteen times) in As You Like It than in any other Shakespeare play. More than one of the memorable speeches exploits the number seven. Of Jaques' 'Seven 
Ages of Man' Marjorie Garber writes, 'The choice of seven for the ages of man was a popular one in Shakespeare's time, although some experts contended that there were three, or four, or six. But seven was the number of the planets, and the virtues and vices, and the liberal arts, and so on. ${ }^{20}$ Garber also cites the echo of Jaques' 'Seven Ages' in the final scene of the play: 'Jaques' portentous seven ages of man speech has its amusing and subversive pendant in Touchstone's account of the seven degrees of the lie. ${ }^{21}$ Harold C. Goddard notes without comment that in 4.1 Jaques enumerates 'seven different types of melancholy'. ${ }^{22}$

Among explicit appearances of 'seven', Rosalind declares in 3.2, 'I was seuen of the nine daies out of wonder, before you came: for looke here what I found on a Palme tree' (170-2). Again in 3.2, Rosalind employs 'seven' twice when she speaks of Time that 'trots hard with a young maid, between the contract of her marriage, and the day it is solemnized: if the interim be but a sennight, Time's pace is so hard, that it seems the length of seuen year' (304-7). Variants of 'seven' appear twice in Old Adam's speech in 2.3:

From seauentie [sic] yeeres, till now almost fourescore

Here liued I, but now liue here no more

At seauenteene yeeres, many their fortunes seeke

But at fourescore, it is too late a weeke ... (71-4)

There are many other manifestations of 'seven' only glanced at by commentators (or wholly overlooked) which I will enumerate as I illustrate allusions in Shakespeare's text to Christopher Marlowe.

\section{The 'Dead Shepheard' of As You Like It}

There can be no argument that As You Like It contains at least one explicit nod to Marlowe, Phebe's declaration to the 'Dead Shepheard' and her quote from his recently published Hero and Leander (1598). ${ }^{23}$ This raises a curious question: why address Marlowe as 'Dead Shepheard'?

The scholarly consensus seems to hold that Phebe's epithet is a wink at what may have been Marlowe's best-known (though unpublished in his lifetime) poem 'The Passionate Shepherd to his Love' (ca. 1592, published 1599). ${ }^{24}$ Its popularity is validated by Raleigh's mocking response, 'The Nymph's Reply to the Shepherd', published in 1600. But Phebe raises more questions than she 
answers. Would an Elizabethan audience casually have accepted a rural shepherdess quoting Marlowe? Imagine an Okie girl in the 1930s - Rose of Sharon Joad in John Steinbeck's The Grapes of Wrath - suddenly spouting a couplet by Yeats; wouldn't that blink readers' eyes and whet the nibs of critics? Literacy was uncommon among Elizabethan women generally and rural women in particular. Wouldn't an Elizabethan audience be surprised by a shepherdess who can read and write? And how could Phebe come by a quarto of Hero and Leander? However, if Phebe is speaking for the playwright, 'Dead Shepheard' assumes a deeper coloration. ${ }^{25}$

Some scholars have suggested that Marlowe had a hand in Shakespeare's earliest history plays, the Henry VI trilogy. ${ }^{26}$ Robert A. Logan believes that Shakespeare composed Titus Andronicus and Richard III 'close to the time Marlowe wrote The Massacre at Paris, a period during which he and Marlowe were known to be working side by side in London (1590-93)'. ${ }^{27}$ If these inferences are valid Marlowe may have supplied the role of inspiration, mentor, and/or collaborator early in Shakespeare's literary career. Both men arrived in London during the same period and their backgrounds were uncannily similar. Marlowe and Shakespeare were born within weeks of each other in Canterbury and Stratford-upon-Avon, comparable towns some distance from London. Both men had fathers named John, and both fathers were leather-workers: John Marlowe a shoemaker, John Shakespeare a whittawer. The great divergence in their lives came with Marlowe's higher education at Cambridge (MA 1587) and the explosive success of his Tamburlaine, Part One that same year.

When Shakespeare arrived in London (I will suggest that in 5.1 he gives the date as 1589) an early acquaintance may have been Thomas Nashe. Gary Taylor argues that Nashe was the author of Act 1 of 1 Henry VI. ${ }^{28}$ Did Marlowe also have a hand in this and other texts? The excessive violence of Titus Andronicus certainly owes something to Thomas Kyd's Spanish Tragedy (ca.1582) or other contemporary works in the genre such as George Peele's The Battle of Alcazar (ca. 1588); indeed, Peele is suggested as co-author of Shakespeare's Roman bloodfest. ${ }^{29}$ But Titus' extravagant language at his entrance in 1.1, 'Hail, Rome, victorious in thy mourning weeds ...' (86-112), surely resonates with Tamburlaine's 'high astounding terms'.

By 1589 Marlowe was a celebrated playwright with Tamburlaine 1 and 2 under his belt; he may have been writing The Jew of Malta or The Massacre at Paris when Shakespeare arrived in London. ${ }^{30}$ 
Why might Marlowe have taken an interest in young Shakespeare? Any answer must be wholly speculative. But we can be confident that the men came from similar backgrounds, that Shakespeare was ambitious to become an actor and playwright, and that he was 'a prettie wit', and perhaps bisexual (Sonnets 18 ff.). ${ }^{31}$ Anne Righter speculates that Shakespeare's honorific for Marlowe as a 'Dead Shepheard' was a 'purely private rite of memory'. ${ }^{32}$ I take it as one poet's expression of gratitude to another. ${ }^{33}$

\section{Encountering a passionate shepherd}

A previously unrecognized indicator that Marlowe's ghost haunts the text of As You Like It appears in one of Shakespeare's gambols - perhaps the best of all his in-jokes. As Rosalind, Celia, and Touchstone enter the forest, whom do they encounter? Silvius, who with his very first line reveals himself as a passionate shepherd: 'O Corin, that thou knew'st how I do loue her' (2.4.20). In case we missed his joke, seventeen lines later Shakespeare's Corin gives us a nudge: 'if thou has not broke from companie, Abruptly as my passion now makes me, Thou hast not lou'd' (37-9, my emphasis). For those who have still missed the passionate shepherd connection Shakespeare crosses the T with Rosalind's rhyming couplet:

Iove, Iove, this Shepherds passion*

Is much vpon my fashion.

(56-7, *my emphasis)

By introducing the passionate shepherd Silvius - and by the repetition of 'passion' - Shakespeare is preparing us to encounter Marlowe among the oaks and brambles of the Forest of Arden. This brings us to another key question.

\section{Was Marlowe the model for Jaques?}

Though he renders an insightful appreciation of As You Like It, for James Shapiro the character of Jaques ${ }^{34}$ remains 'something of an enigma. He has a significant presence in the play (speaking almost a tenth of its lines), but no effect on it. He changes nothing, fails to persuade or reform anyone. ${ }^{35}$ One could say as much for Sir Oliver Mar-text and Audrey's would-be suitor, William (I will suggest that all three roles constitute a miniature roman à clef). Shapiro's Jaques 
is 'melancholy, brooding, and sentimental, and some have seen in him a rough sketch for Hamlet; others find him little more than a self-deluding, jaundiced, one-time libertine. ${ }^{36}$ Jaques will shrug off his enigmatic wrapper as we assess more than a dozen qualities that the Libertine of Arden has in common with Christopher Marlowe.

\section{Jaques a poet}

As 1 Lord describes Jaques mooning over the pageant of a wounded deer, Duke Senior asks: 'But what said Iaques? Did he not moralize this spectacle?' To which 1 Lord replies: 'O yes, into a thousand similes' (2.1.43-5). Moralizing in similes is what poets do, and Marlowe was a past master. ${ }^{37}$ In 2.5 Jaques displays his poetical bent by reciting a verse he has authored as a stanzo for Amiens' first song:

If it do come to passe,

that any man turne Asse:

Leauing his wealth and ease,

A stubborne will to please,

Ducdame, ducdame, ducdame:

Heere shall he see, grosse fooles as he,

And if he will come to me. (45-50)

With this doggerel Shakespeare presents Jaques as unmistakably a poet, and one with an attitude. The first thing we learn about Jaques is that he is a poet as Marlowe was.

\section{Jaques thinks like a playwright}

The 'Seven Ages of Man' speech smacks of the ruminations of a playwright. It begins:

All the world's a stage,

And all the men and women, meerely Players;

They haue their Exits and their Entrances, And one man in his time playes many parts, His Acts being seuen ages. (2.7.140-4)

Here we have 'stage', 'Players', 'Exits', 'Entrances', 'playes', 'parts', and 'Acts' in a single breath, a cascade of the language of the theatre. Jaques continues,

At first the Infant,

Mewling, and puking in the Nurses armes:

Then, the whining Schoole-boy with his Satchell 
And shining morning face, creeping like snaile

Vnwillingly to schoole. And then the Louer,

Sighing like Furnace, with a wofull ballad

Made to his Mistresse eye-brow. Then, a Soldier,

Full of strange oaths, and bearded like the Pard,

Ielous in honor, sodaine, and quicke in quarrell,

Seeking the bubble Reputation

Euen in the Canons mouth: And then, the Iustice

In faire round belly, with good Capon lin'd,

With eyes seuere, and beard of formall cut,

Full of wise sawes, and moderne instances,

And so he playes his part. The sixt age shifts

Into the leane and slipper'd Pantaloone,

With spectacles on nose, and pouch on side,

His youthfull hose well sau'd, a world too wide,

For his shrunke shanke, and his bigge manly voice,

Turning againe toward childish trebble pipes,

And whistles in his sound. Last Scene of all,

That ends this strange euentfull historie,

Is second childishnesse, and meere obliuion,

Sans teeth, sans eyes, sans taste, sans euery thing. (144-67)

What playwrights write is dialogue. And each of Jaques' ages is characterized by a speaking voice: the infant 'Mewling', the schoolboy 'whining', the lover 'Sighing ... a ... ballad', the soldier 'Full of strange oaths', the justice 'Full of wise sawes, and moderne instances', the pantaloon's 'bigge manly voice, Turning againe toward childish trebble', and the last act mere babble. This is the diction of a playwright analysing the particular requirements for writing dialogue for each of these characters.

\section{Jaques a social scold}

\section{Lord says of Jaques,}

Thus most inuectiuely he pierceth through

The body of Countrie, Citie, Court, Yea, and of this our life, swearing that we

Are meere vsurpers, tyrants ... (2.1.58-61)

Social criticism is what playwrights do. Jaques tells us this is a role he relishes. Then he announces his ambition to become a fool. What is a fool? An amalgam of social critic and entertainer. 
The Wise-mans folly is anathomiz'd

Euen by the squandring glances of the foole.

Inuest me in my motley: Giue me leaue

To speake my minde, and I will through and through

Cleanse the foule bodie of th'infected world,

If they will patiently receiue my medicine. (2.7.56-61)

In Jaques' succeeding speech, 'Why who cries out on pride ...' (70-87), he proclaims that the follies he'll castigate are so common among society that he'll easily escape censure, an important consideration for any Elizabethan playwright wishing to keep his career and fingers intact. This speech also contains Shakespeare's wink at a line from his 2 Henry VI which Marlowe cribbed in Edward II. Jaques declares: 'What woman in the Citie do I name, When that I say the City woman beares The cost of Princes on vnworthy shoulders?' (2.7.74-6). Shakespeare's Margaret had mocked the ambitious Eleanor, saying, 'She beares a Dukes Reuenewes on her backe' (1.3.78), before Marlowe's Mortimer sneered at the baseborn Gaveston, 'He weares a lords reuenewe on his back' (1.4.406).

\section{Jaques a traveller}

Marlowe's travels were controversial if not notorious. The fellows of Cambridge were inclined to deny his MA because they suspected Marlowe's intention to convert to Roman Catholicism and join the English recusant college at Rheims. It took a rare intervention by the Privy Council on 29 June 1587 to secure Marlowe's degree in respect of his prior 'faithful dealing' and 'good service' to the Queen. ${ }^{38}$ It may well be that Marlowe had travelled to the Continent as a spy for Walsingham's secret service. ${ }^{39}$

Shakespeare drops two tantalizing hints that Jaques may have travelled abroad. The first appears in 2.5 when Jaques demands more song of Amiens: 'Come, more, another stanzo: Cal you 'em stanzo's?' (15). One is struck by the appearance of 'the fashionable Italian name for a verse, first recorded by the Oxford English Dictionary (OED) in Greene's Menaphon (1589), and first used by Shakespeare in $L L L^{340}$ Here Shakespeare uses the word twice for emphasis. Later, Rosalind calls after him:

Farewell Mounsieur Trauellor: looke you lispe, and weare strange suites; disable all the benefits of your owne Countrie: be out of loue with your natiuitie, and almost chide God for making you that 
countenance you are; or I will scarce thinke you haue swam in a Gundello. (4.1.30-4)

Her 'Gundello' reference (modern: gondola) winks at Italy; it appears unlikely that Marlowe had travelled that far, though Robert Greene certainly did. ${ }^{41}$ In an effort to blend in while abroad, Marlowe-the-spy may have adopted local fashions and patterns of speech. To insinuate himself among recusants abroad wouldn't a spy be wise to repudiate his country and 'chide God' for having been raised a Protestant in the shadow of Canterbury Cathedral? On his return from Europe, Marlowe - ever the faddist and dandy (viz. his putative portrait in Corpus Christi College, Cambridge) may have affected his speech and attire, or lampooned Englishmen who did.

It is also noteworthy that Rosalind's description of an Italianate Elizabethan traveller is an unmistakable echo of Nashe's portrait of Gabriel Harvey during his encounter with the Queen at Audley End in Have with you to Saffron-Walden: 'the Italian that wore crowns on his shoes, and quite renounced his natural English accents \& gestures, \& wrested himself wholly to the Italian punctilios, speaking our homely island tongue strangely, as if he were but a raw practitioner in it, $\&$ but ten days before had entertained a schoolmaster to teach him to pronounce it. ${ }^{, 42}$ Below I will suggest that Nashe, in the person of Touchstone, is another lurking presence in Shakespeare's greenwood.

\section{Jaques an atheist}

One of the most baffling passages in As You Like It appears in the verse Jaques claims to have 'made yesterday in despite of my invention':

Ducdame, ducdame, ducdame:

Heere shall he see, grosse fooles as he,

And if he will come to me. (2.5.40-1)

Hearing this, Amiens says, 'What's that ducdame?' and Jaques replies, 'Tis a Greeke inuocation, to call fools into a circle' (48-52).

The elusive meaning of 'ducdame' has been endlessly debated. In his edition of 1765 Dr Johnson thought that Sir Thomas Hanmer 'very acutely and judiciously read $d u c$ ad me. That is, bring him to me. ${ }^{43}$ The Variorum follows this remark with two pages of risible if 
well-intentioned guesses. ${ }^{44}$ In fact, Hanmer and Johnson came close to the truth. The correct solution can be found in Jaques' explanation that his (obvious) nonsense word is a 'Greek inuocation, to call fools into a circle'. This may be a wink at the the Collecta or Oratio ad collectam, a form of invocation for gathering the faithful which dates from at least the era of Leo the Great (AD 440-61); it summoned believers to join the procession into the church to celebrate the Eucharist. The rite is commonly known in both Catholic and Anglican liturgies as a 'Collect', spelled as the common word for 'gather' but pronounced käl' likt or käl' lekt. ${ }^{45}$

Marlowe was formally schooled in Anglican ritual. He went up to Cambridge in 1581 on a scholarship established by Archbishop Matthew Parker for students preparing to enter holy orders. ${ }^{46}$ After completing his education, instead of taking the cloth Marlowe became infamous as an atheist. Jaques, whom Shakespeare endowed with Marlowe's erudition and attitudes, has fashioned 'ducdame' by anagrammatizing the Latin ' $d u c$ ad me' into a nonsense word he characterizes as a 'Greeke inuocation' to gather the foolish together. In fact, his 'ducdame' parodies the Collect which conveys the priest's welcome to congregants as they arrive, and sets the theme for the day's religious service. ${ }^{47}$ But why does Jaques claim his Latinate anagram as Greek?

Because Elizabethans believed the anagram was a Greek invention, the brainchild of the poet-librarian Lycophron (third century BC) and his circle. In his Arte of English Poesie, George Puttenham cites Lycophron's as the earliest examples of the form. ${ }^{48}$ When Jaques says 'Greek', Shakespeare is saying 'anagram'.

Jaques's assertion that his 'Greek' Collect draws 'fools into a circle' is an atheist's scathing mock of the rite of Communion and its believers. In Twelfth Night, Sebastian will spurn the agrammatizing Feste as a 'foolish Greek' (4.1.16; see the discussion below).

Moments later Jaques delivers another odd pronouncement: 'Ile go sleepe if I can: if I cannot, Ile raile against all the first borne of Egypt' (2.5.53-4). Delusional or over-imaginative Oxfordians take this as a reference to the Seventeenth Earl's bouts of insomnia. Rather, it is Jaques' glance at the original railer against the children of Egypt, Moses: 'And all the first borne in the lande of Egypt shall die, from the first borne of Pharaoh that sitteth on his throne, vnto the first borne of the maide seruant that is at the mille, and all the first borne of beastes' (Exodus 11:5). Jaques is declaring that he 
intends to carry on 'invectively' against usurpers, that is, against the rich and privileged of society - particularly the hereditary aristocracy whose wealth and power derived from being first-born into an Elizabethan society which observed the law of primogeniture precisely the law which frustrates Orlando, and which Shakespeare's cognomen for the exiled Duke Senior emphasizes.

\section{Jaques a beast}

Scene 2.7 opens with Jaques nowhere to be found and Duke Senior speculating, 'I thinke he be transform'd into a beast, For I can no where finde him, like a man' (1-2). This is another of Shakespeare's in-jokes. Marlowe's nickname was 'Kit', which OED cites both as an abbreviation for 'Christopher' and as slang for a beast - 'a cat or any small, furry animal (particularly the young of a fox)'. Shakespeare's logic runs: Kit:= Christopher; kit:= beast $\therefore$ Christopher $\leftrightarrow$ beast.

\section{Jaques a reprobate}

When Jaques appears in 2.7 he reports the discovery of a fool in the forest, Touchstone. This sends him into a paroxysm of railing which begins:

\section{I must haue liberty}

Withall, as large a Charter as the winde,

To blow on whom I please, for so fooles haue:

And they that are most gauled with my folly,

They most must laugh: (47-51)

Jacques proclaims his ambition to be a social scold, as Nashe was, and predicts that his auditors will find his Jeremiads hilarious even as they recognize themselves as the butt of his humour. But Jaques' demand elicits a stern rebuke from Duke Senior, one which reveals a personal backstory that we could not have guessed:

Most mischeeuous foule sin, in chiding sin:

For thou thy selfe hast bene a Libertine,

As sensuall as the brutish sting it selfe,

And all th'imbossed sores, and headed euils,

That thou with license of free foot hast caught,

Would'st thou disgorge into the generall world. (64-9)

Curiously, the Duke's denunciation has no precedent in the play. We've received no prior hint that Jaques has led a disreputable 
life - but Marlowe did. He was frequently in trouble with the law, having been

arrested on 18 September 1589 for his part in the killing of William Bradley by his friend Thomas Watson, and on 26 January 1592 for coining in Flushing in the Netherlands; on 9 May 1592 he was bound over in the sum of $£ 20$ to keep the peace towards Allen Nicholls, Constable of Holywell Street, Shoreditch, and Nicholas Helliott, beadle, and to appear at the General Sessions in October; and on 15 September 1592 he was arrested for fighting in the streets of Canterbury with a tailor named William Corkine. ${ }^{49}$

Marlowe was also under caution from the Privy Council at the time of his death.

The Duke's censure can be read as an indictment of Marlow's profligate and (by Elizabethan standards) perverse lifestyle. In point of fact, shortly before Shakespeare began writing As You Like It, Marlowe's memory had been desecrated in two publications, one in 1597 by Thomas Beard, a puritan divine, and the other a year later by Frances Meres, both citing the poet's 'Epicurisme and Atheism'. ${ }^{50}$ Perhaps this is why Shakespeare was so discreet in framing his tribute to Marlowe (sufficiently discreet that no scholar has detected it in four hundred years). Though the dead man's plays continued to hold the stage throughout Shakespeare's career, Marlowe-the-man had become an object of controversy, scorn, and derision.

\section{Duke Senior breaks the fourth wall}

Scene 2.7 includes both Jaques' 'Seven Ages of Man' speech and a response, Amiens' song 'Blow, blow, thou winter winde'. But first Duke Senior delivers a remarkable declaration which seems to breach the fourth wall of the theatre and involve the playhouse audience and London itself in the drama: 'This wide and vniuersall Theater Presents more wofull Pageants then the Sceane Wherein we play in' (138-9). Shakespeare is asking his auditors to receive what follows in a context far broader than the narrow stage on which the actors stand.

This is Jaques' cue; indeed, he completes Duke Senior's shortened line with 'All the world's a stage' and the so the great speech begins. As it ends, Orlando enters bearing Adam - a mere eight lines suffice to set him to meat - after which Amiens' song follows: 
Blow, blow, thou winter winde,

Thou art not so vnkinde, as mans ingratitude

Thy tooth is not so keene, because thou art not seene, although thy breath be rude.

Heigh ho, sing heigh ho, vnto the greene holly,

Most frendship, is fayning; most Louing,meere folly:

The heigh ho, the holly,

This Life is most iolly.

Freize, freize, thou bitter skie that dost not bight so nigh as benefitts forgot:

Though thou the waters warpe, thy sting is not so sharpe as friend remembred not.

Heigh ho, sing, \&c. (175-94)

Dusinberre notes that 'Amiens' song recapitulates the Duke's opening speech in 2.1 , bringing Act $2 \ldots$ to a harmonious finale. ${ }^{51}$ But perhaps the song has a more important metadramatic function. If Amiens' song is read not as a bookend for the Duke's opening speech but as a reply to the dramatist in Jaques' 'Seven Ages' speech, Amiens' lyrics could be read as a dirge for Marlowe. Its principal theme is 'mans ingratitude'. Could this be a glance at Marlowe's homicide? Was the ingratitude the Privy Council's? Did they (or certain of their members) sanction Marlowe's death even though he had done the Queen good service as a spy? Then there is the matter of false friendship: 'Most friendship, is fayning'. Surely the men who murdered Marlowe were friends who proved false. Is Shakespeare hinting at the name of one false friend with 'Freize, freize, thou bitter skie'? The man who stabbed Marlowe was Ingram Frizer; his name was pronounced 'Freezer', and variously spelled in legal documents 'Frezer' and 'Ffrezer'. The words 'benefitts forgot' could refer to Marlowe's 'good service' to the Queen ignored by his killers. Or it could refer to maimed funerary rites; Marlowe was buried on the day after his death in an unmarked grave in an out-of-the-way church in an out-of-theway suburb, hardly a fitting interment for the greatest English poet since Chaucer. ${ }^{52}$

This is a poser. Could Amiens' song be Shakespeare's meditation on the questionable death and hugger-mugger burial of Christopher Marlowe, and an indictment of his killers and their masters? Certainly, Duke Senior's shattering of the fourth wall encouraged auditors to relate Jaques' speech and Amiens' song to the 'vniuersall 
Theater' - the wider world - perhaps to a tragic event in the life of the London theatre.

\section{Jaques a homosexual}

Curiously for a 'libertine', Jaques takes no interest in any of the female characters of the play. Indeed, only two characters seem to catch his fancy. The first is young Orlando, with whom he briefly fences in 3.2 before offering an invitation: 'You haue a nimble wit ... Will you sitte downe with me?' (268-70). Rebuffed by Orlando, Jaques declares, 'The worst fault you haue, is to be in loue' (274), that is, Orlando should be faulted for being in love with a woman (fault = female genitalia).

Jaques' second interest is Rosalind disguised as Ganymede, namesake of Zeus' toy-boy in Marlowe's Dido, Queen of Carthage. She will tersely blow off Jaques in 4.1 (see the discussion below). If Shakespeare were to write a play remembering the homosexual Marlowe, what better vehicle could he choose than the story of a girl pretending to be a boy pretending to be a girl teaching a boy to woo him or her ${ }^{23}$ One can see how, in the mind of a playwright, the ghost of Marlowe and the adventures of Rosalind-Ganymede could easily cohabit As You Like It. ${ }^{54}$

\section{Jaques a spy}

As noted, some scholars reckon that Marlowe served as an agent for Elizabeth's spymaster, Walsingham, and that the association may have led to Marlowe's death. ${ }^{55}$ Marlowe's three companions in the room at Deptford were all sometime operatives or fellow travellers of the spy service. ${ }^{56}$ In As You Like It Shakespeare touches on this aspect of Marlowe's career so lightly that scholars have never recognized it.

The moment comes in 3.3, a scene rife with allusions to Marlowe's life and death. Touchstone, courting Audrey, laments his rusticated circumstances:

Clo. I am heere with thee, and thy Goats, as the most capricious Poet honest Ouid was among the Gothes.

Iaq. O knowledge ill inhabited, worse then Ioue in a thatch'd house.

Clo. When a mans verses cannot be vnderstood, nor a mans good wit seconded with the forward childe, vnderstanding: it strikes a man more dead then a great reckoning in a little roome: truly, I would the Gods hadde made thee [Audrey] poeticall. (5-14) 
Agnes Latham's (undervalued) note on this exchange deserves reconsideration. She recalls that Ovid, exiled among the Getae, complained that in their barbarous country his verses were not understood.

'A hearer rouses zeal, excellence increases with praise, and renown possesses a mighty spur. In this place who is there to whom I can read my compositions?' (Ex Ponto 4.2.15-38) ... Cf. Nashe, Pierce Pennilesse, 1592: 'Ouid might as well have read his verses to the Getes that vnderstood him not'. $(1.180)^{57}$

Latham has noticed that Touchstone's Ovid 'among the Gothes' isn't directly referencing the Latin poet's Ex Ponto as other commentators have supposed. ${ }^{58}$ Rather, Shakespeare is remembering the predicament of Ovid as expressed by Nashe in Pierce Pennilesse. Shakespeare links Nashe with Touchstone via their identical references to Ovid.

Overhearing Touchstone's moan, Jaques-Marlowe, hidden and spying, grumbles, ' $\mathrm{O}$ knowledge ill inhabited, worse then Ioue in a thatch'd house', a glance at the story of Philemon and Baucis in Ovid's Metamorphoses; the exiled Roman poet was frequently at the sharp end of Marlowe's and Nashe's pens. ${ }^{59}$ On the instant Touchstone delivers one of the play's putative references to Marlowe: 'it strikes a man more dead then a great reckoning in a little roome' (12-13).

The irony of Touchstone's allusion to the homicide of Marlowe being overheard by the ghost of Marlowe hovering a spy in the underbrush is breathtaking.

Moments later, Sir Oliver Mar-text enters, a character Shakespeare endows with a name unambiguously linked to Nashe via his Marprelate texts. It's difficult to discover the dramatic function of this scene; in return for her favours Audrey could have demanded a proper marriage to Touchstone without the intervention of either Mar-text or Jaques. Likewise, the scene in which William comes seeking Audrey's favour and is rebuffed by Touchstone (5.1) appears to have no dramatic function. One can't justify either scene - or the intrusion of the characters Mar-text and William by arguing dramatic necessity. What, then, are the functions of the Mar-text and William scenes?

I suggest that the former illustrates episodes in Marlowe's and Nashe's careers while the latter is autobiographical. Scene 3.3 shows 
us a spying Jaques-Marlowe overhearing Touchstone-Nashe's 'great reckoning' lines, and Clown-Nashe brought face to face with a Mar-text. Below I will suggest that 5.1 functions to introduce a bumpkin named William (Shakespeare) and give us the date of his first encounter with London's theatrical scene.

\section{Jaques a melancholic}

Scene 4.1 begins with (homosexual) Jaques courting the 'boy' Rosalind-Ganymede: 'I prithee, pretty youth, let me be better acquainted with thee' (1-2). Lifted from its context, surely this is an archetypal Elizabethan pick-up line.

Brushed off by Orlando in 3.2, Jaques - the notorious 'libertine' and sinner who inexplicably ignores Celia, the play's only available female - now tries his luck with the play's other boy-figure. But canny Rosalind is miles ahead of him. She replies, 'They say you are a melancholy fellow ... Those that are in extremity ... are abhominable fellowes, and betray themselues to euery moderne censure, worse then drunkards' (3-7).

Her response, which seems to echo Duke Senior's indictment of Jaques - even though Rosalind wasn't present when the Duke spoke - is framed to shield herself while revealing the personality of Jaques. One could argue it is precisely the Duke's and Rosalind's indictments of Jaques which made the Jaques-Marlowe connection transparent to Shakespeare's first auditors. ${ }^{60}$ Righter was particularly struck by these censures: 'one almost wonders if they were intended to evoke the image of Marlowe for the playgoers at The Globe'. ${ }^{61}$

Within a breath Jaques does his best to make himself sound interesting and even exotic:

I haue neither [1] the Schollers melancholy, which is emulation: nor [2] the Musitians, which is fantasticall; nor [3] the Courtiers, which is proud: nor [4] the Souldiers, which is ambitious: nor [5] the Lawiers, which is politick: nor [6] the Ladies, which is nice: nor [7] the Louers, which is all these ... (10-14, my enumeration)

Jaques lists seven forms of melancholy - while writing As You Like It the number seven is inextricably bound up with Marlowe in Shakespeare's mind - none of which is his. Jaques has 'a melancholy of mine own' (the melancholy of a poet?) which he couches in terms meant to make him sound interesting. ${ }^{62} \mathrm{He}$ says it is 'compounded 
of many simples, extracted from many obiects, and indeed the sundrie contemplation of my trauells, in which by often rumination, wraps me in a most humorous sadnesse' (15-18). Travellers were not so common then as now and, if not vagabonds, might be people worth knowing. But Rosalind is ahead of Jaques again and turns his travels against him: 'A Traueller: by my faith you haue great reason to be sad: I feare you haue sold your owne Lands, to see other mens; then to haue seene much, and to haue nothing, is to haue rich eyes and poore hands' (19-22). As noted, Marlowe's travels had almost cost him his MA. For want of money he was arrested for counterfeiting in the Netherlands. Indeed, if his homicide was related to his spying his travelling may have cost him his life.

As Orlando arrives, Rosalind sees off Jaques with her evocative reference to a 'Gundello'. But not before Jaques-Marlowe pronounces what is unmistakably a playwright's benediction (or curse): 'Nay then God buy you, and you [Orlando] talke in blanke verse' (28-9) - which Orlando pointedly does not do for the balance of the scene. Even after Jaques has left the stage, Marlowe is still lurking in Shakespeare's mind and is again memorialized when Rosalind rehashes (and debunks) the tale of Hero and Leander (91-9).

As to Jaques' characterization of his personal form of melancholy, the phrase 'compounded of many simples' may be what it appears to be - a figure of speech. But it could also be a glance at Marlowe's use of recreational substances. 'Simples' were medicinal herbs, tobacco being one. The Frenchman Jean Nicot described its medicinal properties in 1559 (hence 'nicotine'), and Raleigh popularized smoking in England in the 1570s. By his own admission Marlowe was an enthusiastic user of tobacco (and boys). The infamous 'Baines Note' quotes Marlowe as saying 'all they that loue not Tobacco \& Boies are fools. ${ }^{63}$ Numerous alcoholic drinks were 'compounded of many simples'; for example, gin, a medieval invention, is distilled with juniper berries (hence the Dutch Jenever). Whether Shakespeare's phrase 'many simples' is a glance at Marlowe's use of psychoactive substances is a nice question; Herodotus (484-425 BC) noted that the Scythians - Tamburlaine's tribe - enjoyed the use of a drug, apparently cannabis. ${ }^{64}$

\section{Jaques no music lover}

To qualify for a Parker Scholarship, Marlowe had to demonstrate an ability to sing plainsong at sight and, perhaps, the wit 'to make 
a verse'; Riggs speculates that Marlowe had learned music at a school organized by Archbishop Matthew Parker 'adjacent to Eastbridge Hospital where Canterbury pilgrims had lodged before the Reformation' ${ }^{65}$

Marlowe may have had unpleasant memories of his musical education. Shapiro notes that 'Marlowe had hated jigs, and said so in the prologue to Tamburlaine the Great, where he announces that his play rejects "jigging veins of riming mother wits And such conceits as clownage keeps in pay." 66 Perhaps this explains why Jaques scorns music in 2.5 and again in 4.2. In the former scene Jaques' stanzo for Amiens' song is a double parody; it sends up the greenwood song itself and simultaneously lampoons Duke Senior's band of merry men. In 4.2 Jaques equates music with noise as he demands the Forrester's song: 'Sing it: 'tis no matter how it bee in tune, so it make noyse enough.' (8-9). It comes as no surprise when in 5.4 Jaques shuns the nuptial festivities, proclaiming, 'I am for other, then for dancing meazures' (191). The 'meazures' that Marlowe favoured were poetical.

\section{Jaques an old gentleman.}

In 5.1 Audrey appears to refer to Jaques when she complains, 'Faith the Priest was good enough, for all the olde gentlemans saying' (3-4). In 1600 Marlowe (and Shakespeare) would have been thirtysix years old - not old by our standards. Then again, age is relative; how old is Audrey? The age of consent was then fourteen for boys, twelve for girls.

Does Audrey's reference to 'olde gentleman' suggest Shakespeare himself played the part of Jaques? ${ }^{67}$ From playhouse in-jokes in the texts, I've suggested that Shakespeare played Caesar in 1599 and Polonius in Hamlet, both older men. ${ }^{68}$ There may be another inside joke here: Shakespeare officially became a 'gentleman' on 20 October 1596. Did Shakespeare's tribute to - and admiration for Marlowe run so deep that he himself played Jaques? Or was taking the role of Marlowe a reflection of Shakespeare's emulation?

\section{Jaques offers seven blessings}

Jaques' career follows a curious arc in the final act of the play. First, Orlando delivers a not-very-oblique allusion to Marlowe's Faustus. He explains that Rosalind-Ganymede, though 'forestborn', was tutored 'Of many desperate studies, by his vnckle, Whom 
he reports to be a great Magitian. Obscured in the circle of this Forrest' (5.4.32-4). Surely, 'desperate studies', 'great Magitian', and 'Obscured in the circle' are echoes of Faustus, who had yearned to be a magician and had many 'desperate thoughts'. These lines are Jaques' cue to speak, and his text is an impious biblical lampoon: 'There is sure another flood toward, and these couples are comming to the Arke' (35-6).

Moments later, Touchstone engages in a veritable fugue on the word 'seven'. He begins by enumerating the seven proofs of his qualifications as a courtier:

I haue [1] trod a measure, I haue [2] flattred a Lady, I haue [3] bin politicke with my friend, [4] smooth with mine enemie, I haue [5] vndone three Tailors, I haue [6] had foure quarrels, and [7] like to haue fought one. (44-7, my enumeration)

Then he briskly moves to his quarrel 'vpon the seuenth cause' which exhausts the next fifty lines - with 'seuenth' repeated four times in eighteen lines. First, Touchstone enumerates the possibilities of a 'lye, seuen times remoued':

I did dislike the cut of a certaine Courtiers beard: he sent me word, if I said his beard was not cut well, hee was in the minde it was: this is call'd the [1] retort courteous. If I sent him word againe, it was not well cut, he wold send me word he cut it to please himselfe: this is call'd the [2] quip modest. If againe, it was not well cut, he disabled my iudgment: this is called, the [3] reply churlish. If againe it was not well cut, he would answer I spake not true: this is call'd the [4] reproofe valiant. If againe, it was not well cut, he wold say, I lie: this is call'd the [5] counter-checke quarrelsome: and so to [6] lye circumstantiall, and the [7] lye direct. (69-81, my enumeration)

Then Touchstone again specifies the seven degrees:

I will name you the de-grees. The first, the Retort courteous: the second, the Quip-modest: the third, the reply Churlish: the fourth, the Reproofe valiant: the fift, the Counterchecke quarrelsome: the sixt, the Lye with circumstance: the seauenth, the Lye direct .... (90-5)

As if we hadn't heard enough sevens, Touchstone adds one more:

I knew when seuen Iustices could not take vp a Quarrell, but when the parties were met themselues, one of them thought but of an If; as if you saide so, then I saide so: and they shooke hands, and swore brothers. (96-100) 
There's another seven yet as Jaques offers seven blessings to the principals:

[to Duke Senior] you to [1] your former Honor, I bequeath your patience, and your vertue, well deserues it. [to Orlando] you to [2] a loue, that your true faith doth merit: [to Oliver] you to [3] your land, and [4] loue, and [5] great allies: [to Silvius] you to a [6] long, and well-deserued bed: [to Touchstone] And you to [7] wrangling, for thy louing voyage Is but for two moneths victuall'd ... (184-9, my enumeration $)^{69}$

So the run of sevens which began with Jaques' 'Seven Ages of Man' speech in 2.7 concludes with a barrage of sevens in 5.4. Given the many traits shared by Jaques and Marlowe - indeed, there's hardly a trait of Jaques not shared with Marlowe - would it not be remarkable if Shakespeare didn't have the seventh anniversary of his shepherd's death in mind as he wrote As You Like It? Not incidentally, both Jaques and Touchstone make exactly seven appearances in the play: ${ }^{70}$ Jaques in $2.5,2.7,3.2,3.3,4.1,4.2,5.4$; Touchstone in 1.2, 2.4, 3.2, 3.3, 5.1, 5.3, 5.4. Readers reluctant to accept Shakespeare's cascade of sevens in As You Like It as occasioned by the seventh anniversary of Marlowe's death are invited to supply a more satisfactory explanation.

\section{Jaques seeks redemption}

The final beat in the career of Jaques which deserves consideration is his turn towards redemption. When he learns from Jaques de Boys 'The Duke hath put on a Religious life, And throwne into neglect the pompous Court', our Jaques determines to seek out the Duke. 'To him will I: out of these conuertites There is much matter to be heard, and learn'd' (182-3). What accounts for Jaques' sudden interest in the contemplative life?

I believe it is a mark of Shakespeare's affection for Marlowe that he allows his melancholy libertine finally to express a desire to seek the keys to salvation. As Marlowe himself wrote in Dr Faustus, 'Never too late, if Faustus can repent' (2.2.84). And Shakespeare's fondness is made palpable by Duke Senior entreating, 'Stay, Iaques, stay' (192). Jaques leaves the stage headed for an 'abandon'd cave', an image tantalizingly suggestive of a hollow grave. Shakespeare has endowed his Jaques with more than a dozen traits of Christopher Marlowe. But in the end he must recognize that Marlowe cannot 
return from the green world to the city and court. His only future is to be hidden within earth.

\section{Enter William}

No commentator has offered a persuasive explanation for the presence in the play of Audrey's would-be wooer, the bumpkin William of 5.1. It is possible this character has an important though never recognized function: to give us the date of William Shakespeare's arrival in London and the beginning of his association with the Elizabethan theatre scene. In his dialogue with Touchstone William confirms that he was born 'i'th Forrest heere' (23), that is, the Forest of Arden, the namesake of which is in Shakespeare's Warwickshire. ${ }^{71}$ William admits he is not 'Learned' (38-9), that is, did not attend university. Most significantly, William is 'Fiue and twentie' years old (20). Shakespeare was baptized on 26 April 1564. My inference is that William's age dates Shakespeare's first encounter with university wits, perhaps in the person of Nashe, and the world of London theatre to his twenty-sixth year, the interval from April 1589 to April 1590. Touchstone may be an effigy of Shakespeare's sometime collaborator, Nashe, the 'little wit' who likely died silenced and broke while Shakespeare was writing As You Like It. Shakespeare may be remembering Nashe for providing his first encounter with London's theatrical world.

Of all the new insights to As You Like It offered in this chapter, this is the most fundamental to our understanding of the arc of Shakespeare's career: if my inference is correct, by his own testimony William Shakespeare was twenty-five when he encountered London's theatrical set. If so, this autobiographical note reduces the interval of his 'lost years' from seven to four. And it places him in London at the very moment when professional theatre was coming into its own. Young Shakespeare was, so to speak, present at the Creation.

\section{Marlowe's fame, Shakespeare's tribute}

As usual in Shakespeare's plays, minor characters may comment on the main action and perhaps suggest the playwright's personal point of view. One minor but extraordinary character in the forest is Phebe ('the bright one'), who not only falls in love with 
Rosalind-Ganymede on first sight but justifies herself by quoting Marlowe's Hero and Leander. How many of Shakespeare first auditors (and more recent ones, for that matter) have actually met a shepherdess who could quote Marlowe? Surely this must have struck Shakespeare's audience as at least a trifle out of the ordinary.

Phebe is Shakespeare's discreet but shining tribute to Marlowe as a poet of enduring importance and popularity. That her 'Dead Shepheard' is Marlowe is widely agreed. And he certainly had been dead for seven years. But why 'Shepheard'? As noted above, the answer could be this simple: perhaps Marlowe's best-known poem was 'The Passionate Shepherd to his Love', which appeared in 1599, shortly before Shakespeare began writing As You Like It. But there could be more significance to Phebe's tribute - if she is speaking for the playwright. Did Marlowe act as mentor, guide, and even protector (shepherd) when the twenty-five-year-old William arrived in London in 1589, encountered Nashe, and embarked on a theatrical career? In 1587 Marlowe had arrived in London with the manuscripts of Tamburlaine 1 and Ovid's Elegies under his arm (perhaps Dido, too). Did Shakespeare do likewise in 1589? And did his scratchings and other notable gifts catch the eye of Marlowe? Were the pair friends, colleagues - perhaps even lovers? We may never be able to answer these questions with confidence. But if the portrait of William in 5.1 is autobiographical, then his fleeting appearance (he speaks a mere tem lines) is pregnant with meaning. Not incidentally, dating Shakespeare's arrival in London to 1589 fits well with received chronologies of his plays. ${ }^{72}$

The arrival of an ephemeral William (Shakespeare) in a district populated by so many sophisticates and literati sublimates the play from an anti-pastoral comedy into a personal memoir - one remembered with the greatest possible fondness, not only for the men behind the masks of Jaques and Touchstone, but for the naïve bucolic in homespun who stumbles into their midst. Is this Shakespeare fondly recalling the innocent he was when he arrived at the threshold of the world of the theatre? If so, it is a snapshot for the ages.

And if Marlowe had meant little to Shakespeare, would he seven years after Marlowe's death - have been moved to construct such an elaborate, affectionate tribute to the man as we discover in As You Like It? 


\section{On the character of Touchstone}

The view of rustic life which Touchstone expresses in his dialogue with Corin (3.2) smacks of Nashe's reflections upon his own period of rustication in Great Yarmouth after the Isle of Dogges fiasco of 1597 as recorded in his newly published Lenten Stuffe (1599). ${ }^{73}$ Flashes of Nashean wit and cynicism illuminate several passages of Touchstone's dialogue, including his encounter with William:

I am ... He sir, that must marrie this woman: Therefore you Clowne, abandon: which is in the vulgar, leaue the societie: which in the boorish, is companie, of this female: which in the common, is woman: which together, is, abandon the society of this Female, or Clowne thou perishest: or to thy better vnderstanding, dyest; or (to wit) I kill thee, make thee away, translate thy life into death, thy libertie into bondage: I will deale in poyson with thee, or in bastinado, or in steele: I will bandy with thee in faction, I will ore-run thee with policie: I will kill thee a hundred and fifty wayes, therefore tremble and depart. (5.1.46-57)

Touchstone sounds very much as though he is reciting a passage of Nashe. Indeed, 2 Lord describes Touchstone as 'the roynish clown' (2.2.8), using a rare adjective not otherwise found in Shakespeare but present in Nashe's Strange Newes (1592), in, 'clownish and roynish jeasts' (1.3.9-10).

Shakespeare's much-discussed excursion on the silencing of wit in 1.2 may be a nod to Nashe as well as Marlowe. The principal victims of the bishops' bonfire were Gabriel Harvey and Nashe, and the small stature of the latter may be remembered in the repetition of 'little wit' and 'little foolery'. Remembrances of Nashe pop up here and there in the text of As You Like It; Touchstone's 'This is the verie false gallop of Verses' (3.2.110) echoes Strange Newes: 'I would trot a false gallop through the rest of his ragged Verses' (1.275.7-8). And Shakespeare's admiration for Nashe may be summarized in an exchange between Jaques and Duke Senior at 5.4.102-5:

Iaq. Is not this a rare fellow my Lord? He's as good at any thing, and yet a foole.

Du.Se. He vses his folly like a stalking-horse, and vnder the presentation of that he shoots his wit. 
Surely, a man must be of short stature to be able to shoot under the belly of a horse.

\section{William Shakespeare at thirty-five}

Everyone knows there is something different about Shakespeare's plays after 1599. I have suggested elsewhere that Julius Caesar, written to open the Bankside Globe in midsummer 1599, is the fulcrum on which Shakespeare's career turns. ${ }^{74}$ It may be that graduating to housekeeper from playwright-for-hire - and having, in effect, his own theatre to work in - brought a feeling of liberation to the writer in Shakespeare. Or it may have been that he entered a period of profound religious doubt. What is certain is that a new maturity of vision and perspective coupled with intense skepticism begins to emerge in his plays.

It is possible that Shakespeare wrote As You Like It as a companion piece to Julius Caesar and that these were among the first plays presented at the Globe. In Caesar Shakespeare poses a colossal question: could a man with the initials J.C. really become a god? Or did his 'power' extend only to the superstitious? ${ }^{75}$ In As You Like It the playwright pays a long-outstanding debt to his dead shepherd on the seventh anniversary of Marlowe's death. Taken together, these two plays mark Shakespeare's debut as a writer of skeptical views and bristling social commentary.

As You Like It embodies not only Marlowe's ghost but his spirit, that is, many of his attitudes toward the follies of Elizabethan convention, law and society. Marlowe was nothing if not an iconoclast who defied convention. ${ }^{76}$ Shakespeare's As You Like It is one of his most seditious plays; Michael Hattaway noticed 'the play interrogates matters of gender, rank, and the social order' ${ }^{77}$ In fact, it slaughters any number of Elizabethans' sacred cows.

One of the play's targets is so-called 'agnatic' primogeniture, the medieval custom by which the estate of a deceased father passed in toto to the senior male descendant. ${ }^{78}$ Orlando is its victim, and Jaques intends to make a career of railing against the rich and privileged - those 'first borne of Egypt'. Another of Shakespeare's targets is the Enclosures Controversy expressed in the plight of Corin, a peasant turned into a laborer by a non-resident capitalist landlord. ${ }^{79}$ The long-simmering controversy would burst into open rebellion in Shakespeare's home county of Warwickshire in the 
so-called Midlands Revolt of $1607 .{ }^{80}$ As for the bucolics of Arden, instead of writing sonnets, blowing reed pipes and discoursing like university professors as they did in popular Eclogues and the plays of Lyly, in As You Like It they are hard-working, poor and embittered. They don't own their flocks or farms, but share-crop or shepherd for (low) wages. Touchstone's anti-pastoral argument contra Corin (3.2.13-82) debunks the genre of pastoral romantic comedy, once so popular on the Elizabethan stage.

Though Shakespeare's play ends in marriages, along the way he derides the solemnity of the wedding ceremony in both the mock marriage of Ganymede and Orlando (4.1.114-27) and the Touchstone-Audrey-Martext episode. Shakespeare also belabors the sanctity of wedlock through repeated banter about cuckoldry and horns, and Rosalind's description of a wife's unruly behavior (4.1.39-46). In 4.2 a deer is given a funeral - another sacrament slighted. All this is pure Marlowe. Shakespeare debunks blood sports with his description of the weeping deer (2.1.33-43), Duke Senior's doubts about the legitimacy of hunting (2.1.21-4), and the foresters' song about horns (4.2.14-19). In going hunting, aren't the Duke and his men unlawful poachers? With a quotation from Marlowe's Hero and Leander Shakespeare debunks love at first sight by putting the line into the mouth of Phebe, who has just fallen in love with a woman dressed as a boy. All this is social commentary with a vengeance.

But the play's most seditious theme may be the unspoken question it raises: is flesh merely a garment? In the Geneva Book of Job, Elizabethans read, 'Thou hast clothed me with skin and flesh, and joined me together with bones and sinews' $(10: 11)$. That is to say, the 'me', the self, exists apart from flesh and bone. In As You Like It Shakespeare presents a girl, Rosalind, disguised as a boy named Ganymede ... the paramour of Zeus in Marlowe's Dido, Queen of Carthage ... acting as the romantic surrogate of a girl ... to teach a boy how to make love to her ... er, him ... er, well, whoever turns you on. If a person is not flesh and bone but the soul, what possible difference can the gender of one's lover make? To judge from Marlowe's predilection and the possible range of Shakespeare's own sexuality, not much. Shakespeare's admiration for and vindication of Christopher Marlowe shines out like golden thread in the fabric of As You Like It. Marlowe's ghost and spirit whisper among the branches of the Forest of Arden. Shakespeare's tribute to his 'Dead 
Shepheard' is a glowing exemplar of the devotion of one poet to another. And to a man whom Shakespeare owed much, and may have felt he owed everything. ${ }^{81}$

\section{Notes}

1 Throughout this chapter, original spelling in As You Like It (First Folio 1623) is taken from David Bevington's online edition: www. internetshakespeare.uvic.ca. Modern lineation from Juliet Dusinberre, ed., As You Like It, The Arden Shakespeare, Series 3. (London: Bloomsbury, 2006).

2 Edward Capell, ed., Mr. William Shakespeare his comedies, histories, and tragedies, set out by himself in quarto, or by the players his fellows in folio, and now faithfully republish'd from those editions in ten volumes octavo; with an introduction, 10 vols (London: P. Leach for J. and R. Tonson, [1767-68]), I.64.

3 Leslie Hotson, The Death of Christopher Marlowe (London: Nonesuch, 1925).

4 Oliver W. F. Lodge, 'Shakespeare and the Death of Marlowe', Times Literary Supplement, 14 May 1925, 335.

5 'The jester's words might in the end be a veiled protest (veiled because delivered by the clown) against the burning on June 4, 1599, by order of the Archbishop of Canterbury and the Bishop of London, of copies of one, or more, of the surreptitious editions of Marlowe's translation of the Elegies of Ovid.' Paul Reyher, 'When a Man's Verses cannot be Understood', Times Literary Supplement, 9 July 1925, 464.

6 Sir Arthur Quiller-Couch and J. Dover Wilson, eds, As You Like It, The New Shakespeare (Cambridge: Cambridge University Press, 1926), 103-5. Ridley grudgingly drew the same conclusion: '[I]t is fair to say that Dr Hotson's discovery of the circumstances of Marlowe's death, in a quarrel over "le recknynge," taken together with the line from The Jew of Malta, Infinite riches in a little room ... have a direct reference to Marlowe ... Finally, besides the obvious Martext-Marprelate connection ... there are some fairly certain allusions to Nashe's Strange Newes (1592) ...' M. A. Ridley, ed., As You Like It, The New Temple Shakespeare (London: J. M. Dent and Sons, 1934), viii-ix. Among current scholarly editions, Brissenden takes exception: 'The comic context here does not suggest such an allusion.' Alan Brissenden, ed., As You Like It, The Oxford Shakespeare (Oxford: Clarendon Press, 1993), 174n. Dusinberre is equivocal: 'often taken to refer to Marlowe's death in 1591 [sic] in a Deptford inn ... However, the great reckoning may be a scatological joke - Hanmer emended to "reeking" - with little room a euphemism for a privy', an impossible notion. Dusinberre, As You Like 
It, 266n. Apparently of no opinion, Hattaway directs the reader: 'For summaries of those who take the line to refer to the mysterious death of Christopher Marlowe at Deptford, see Knowles [Variorum Edition], 188-90.' Michael Hattaway, ed., As You Like It, The New Cambridge Shakespeare (Cambridge: Cambridge University Press, 2009), 163n.

7 Richard Wilson argues that Marcade, messenger of death in Love's Labour's Lost - perhaps written in the months immediately following Marlowe's death - remembers Navarre's servant Mercury in The Massacre at Paris, and perhaps Marlowe's identification with that equivocal god. Richard Wilson, “Worthies away”: The Scene Begins to Cloud in Shakespeare's Navarre', in Jean-Christophe Mayer, ed., Representing France and the French in Early Modern English (Newark, DE: University of Delaware Press, 2008), 95-7.

8 Citations from Martin Spevack, The Harvard Concordance to Shakespeare (Cambridge, MA: Belknap Press, Harvard University Press, 1973). I am deeply indebted to Ms Jocelyn Medawar, a devoted, enlightened Shakespearean and teacher at the Harvard-Westlake School in Los Angeles, both for calling my attention to appearances in the play of 'seven' which I had not previously noticed, and for inspiring my son, David, with a love of the subject.

9 I'm indebted to Professor François Laroque for reading an early draft of this chapter and offering wise and helpful counsel.

10 The earliest appearing in Edmond Malone's chronology of the plays in Johnson's and Steevens' edition of 1778, V.307. James Shapiro has written a thoughtful appreciation of As You Like It into his study of Shakespeare's annus mirabilis, 1599. Yet he seems to believe Shakespeare dashed off this play and others: 'In the course of 1599 Shakespeare completed Henry the Fifth, wrote Julius Caesar and As You Like It in quick succession, then drafted Hamlet.' James Shapiro, A Year in the Life of William Shakespeare: 1599 (New York: HarperCollins, 2005), 4. Even from a playwright of Shakespeare's unique capabilities, this would require an (improbably) Herculean effort. As Verity notes, 'One may with justice ... be loth to use the word "haste" in connection with a work which for many readers is the high-water mark of Shakespeareian [sic] comedy.' A. W. Verity, As You Like It, The Pitt Press Shakespeare for Schools (Cambridge: Cambridge University Press, 1899, repr. 1932), xiii.

11 Richard McCabe, 'Elizabethan Satire and the Bishops' Ban of 1599',Yearbook of English Studies 11 (1981), 192.

12 'Marlowe never mentions Shakespeare, nor would Shakespeare allude to Marlowe until the turn of the [seventeenth] century, when his mighty rival had been dead for seven years.' David Riggs, The World of Christopher Marlowe (London: Faber and Faber, 2004), 281. 
13 Jacobus de Voragine, The Golden Legend, ed. F. S. Ellis, 6 vols, Temple Classics (London: J. M. Dent, 1900, reprinted 1922, 1931), VI.57-8.

14 Jenny Kermode, Medieval Merchants: York, Beverley and Hull in the Later Middle Ages (Cambridge: Cambridge University Press, 2002), 131.

15 Clive Burgess, “By Quick and by Dead”: Wills and Pious Provision in Late Medieval Bristol', English Historical Review 102.405 (1987), 837-58.

16 Martin Luther's Small Catechism (1529) taught that 'We should pray for ourselves and for all other peoples, even for our enemies, but not for the souls of the dead' (Small Catechism, St Louis: Concordia, 2008). Likewise, John Calvin declared the practice of praying for the dead ungodly in his Institutes of the Christian Religion (1536). Even so, the first Anglican Book of Common Prayer (1549) had included a prayer for the dead. Morgan Dix, ed., The Book of Common Prayer 1549, facsimile (New York: Church Calendar Press, 1881), 217. Beginning with the edition of 1552, this language and the practice vanished (it was somewhat restored in the early twentieth century). Anglicans also discarded the Catholic celebration of All Souls (2 November) but re-imagined the Feast of All Saints (1 November) by redefining 'saints' as 'all believers', and used the occasion to commemorate deceased family and friends.

17 Annemarie Schimmel, The Mystery of Numbers (Oxford: Oxford University Press 1993), 156-64.

18 Ibid., 179.

19 Robert Pont, A Newe Treatise of the Right Reckoning of Yeares and Ages of the World, and Mens Liues, and of the Estate of the last decaying age thereof, this 1600 year of Christ (erroneously called a Yeare of Iubilee), which is from the Creation the 5548 yeare; containing sundrie singularities worthie of observation, concerning courses of times and revolutions of the Heaven, and reformation of Kalendars and Prognostications, with a Discourse of Prophecies and Signs, preceding the last daye, which by manie arguments appeareth now to approach (Edinburgh: Robert Walde-grave, 1599).

20 Marjorie Garber, Shakespeare After All (New York: Pantheon Books, 2004), 451-2.

21 Ibid., 452.

22 Harold C. Goddard, The Meaning of Shakespeare, 2 vols (Chicago: University of Chicago Press, 1960), I.266. For a précis of scholarly opinion regarding Touchstone's 'a great reckoning in a little roome' as a glance at Marlowe's homicide and the coroner's conclusion that he was killed in a brawl over the bill see Richard Knowles, ed., As You Like It, A New Variorum Edition of Shakespeare (New York: MLA, 1977), 188-90. 
23 For example: 'Marlow's lyric, "The Passionate Shepherd to his Love", was well known and drew a number of verse replies including versions by Raleigh and Donne.' Hattaway, As You Like It, 174n.

24 'The terms of the debate [between romantic and realistic views of country life] are reproduced ... in Shakespeare's As You Like It, which clearly refers to Marlowe's death and speaks of Marlowe himself as a "dead shepherd" before quoting from Hero and Leander, and in The Merry Wives of Windsor ... in which Parson Evans quotes from "The Passionate Shepherd". Lastly, Marlowe himself recurs to "The Passionate Shepherd" when he has Ithamore quote from it in The Jew of Malta (IV, ii, 110-11).' Hopkins, Christopher Marlowe, 47-8.

25 Marlowe's pastoral poem was still popular and eliciting response forty years after his death, e.g. John Donne's 'The Bait' (pub. 1633).

26 Edward Burns, ed., King Henry VI, Part 1, The Arden Shakespeare, Series 3 (London: Bloomsbury, 2000), 75.

27 Logan sees likenesses of Marlowe's Duke of Guise in Shakespeare's Aaron and Richard III. Robert A. Logan, Shakespeare's Marlowe: The Influence of Christopher Marlowe on Shakespeare's Artistry (Aldershot: Ashgate Publishing, 2007), 31.

28 Gary Taylor, 'Shakespeare and Others: The Authorship of Henry the Sixth Part One', Medieval and Renaissance Drama in England 7 (1995), 145-205.

29 Marlowe's Tamburlaine and Kyd's Spanish Tragedy inspired any number of bloody sequents, e.g. Robert Greene's Alphonsus King of Aragon (ca. 1588); Thomas Lodge's Wounds of the Civil War (ca. 1589); George Peele's The Battle of Alcazar (ca. 1590).

30 Logan believes that 'The Massacre at Paris had to have been written after the death of Henry III on August 2, 1589.' Logan, Shakespeare's Marlowe, 31.

31 'Prettie wit' could mean young William was clever with words. Or it could be that he was pretty as well as witty.

32 Anne Righter, Shakespeare and the Idea of the Play, Penguin Shakespeare Library (London: Penguin, 1967), 139.

33 What might Shakespeare have learned at Marlowe's knee? Speculatively: the power of blank verse; the art of mining history for theatrical high drama; that the Aristotelian unities were not sacred; suspense and tragedy could be heightened by a sudden infusion of comedy; the greatest drama is not physical action but the psychological struggle within a character's mind; and that a playwright could safely comment on the foibles of contemporary Londoners by writing about long-dead historical figures and/or foreign locales. Marlowe's plays 'examine some of the central cultural and religious issues of his day, and each of these plays 
has its finger firmly on the pulse of a crucial aspect of its historical moment.' Hopkins, Christopher Marlowe, 166.

34 The pronunciation of 'Jaques' has been much debated, whether the monosyllabic 'Jakes' or the bi-syllabic 'Ja-kwees' as required by the metre at 2.1.26 and 5.4.192. The only other appearance is in All's Well that Ends Well, when Helena writes that 'i am saint jaques' pilgrim' and has gone towards his shrine at Campostella, Spain. It would seem Shakespeare preferred a spelling without the 'c', and heard the monosyllabic 'Zhok' or 'Jakes'.

35 Shapiro, A Year, 46.

36 Ibid.

37 For example: Riggs notes that 'Tamburlaine the Great, Marlowe's upwardly mobile poet-hero, serenades his future queen with hyperbolic epithets ... "lovelier than the love of Jove, / Brighter than is the silver Rhodope, / Fairer than whitest snow on Scythian hills ...' (1.2.879). Riggs, The World, 56.

38 Privy Council, Letter to the Fellows of Cambridge University, 29 June 1587, The National Archives, Kew, Privy Council Registers PC2/14/381.

39 Park Honan imagines that Marlowe 'sailed through the Paris embassy ... there are signs that he delivered and picked up letters there ... [H]e depicts Paris with easy confidence' in The Massacre at Paris. Park Honan, Christopher Marlowe, Poet and Spy (Oxford: Oxford University Press, 2005), 150.

40 Dusinberre, As You Like It, 211n.

41 Rosalind's 'Gundello' would better fit with the travels of the author and playwright Robert Greene (1558-92), whose 'autobiographical pamphlets reveal that he fell in with "wags as lewd as myself, with whom I consumed the flower of my youth, who drew me to travel to Italy". Riggs, The World, 100.

42 R. B. McKerrow, ed., The Works of Thomas Nashe, 5 vols (London: Sidgwick \& Jackson, 1904-10, repr. Oxford: Basil Blackwell, 1958), III.76.

43 Knowles, As You Like It, 106.

44 Ibid., 106-7.

45 See for example: C. Frederick Barbee and Paul F. M Zahl, eds, The Collects of Thomas Cranmer (Cambridge: W. B. Eerdmans, 1999), xi ff.

46 'The archbishop [Parker] endowed these awards for boys "who were likely to proceed in the Arts and afterwards make Divinity their study".' Riggs, The World, 70.

47 The following are two typical Collects from the Book of Common Prayer. For Christmas: 'God, whiche makest us glad with the yerely remembraunce of the birth of thy onely sonne Jesus Christ; graunt that 
as we joyfully receiue him for our redemer, ....' For Easter: 'Almightie God, whiche through thy onely begotten sonne Jesus Christ hast overcome death, and opened unto us the gate of everlasting life ...'.

48 George Puttenham, The Arte of English Poesie (London, 1589), 90.

49 Hopkins, Christopher Marlowe, 4. On 18 May 1593 the Privy Council had ordered Marlowe's arrest, and on 20 May commanded him 'to give his daily attendance to their lordships, until he shall be licensed to the contrary.' Riggs, The World, 325.

50 In Thomas Beard's The Theatre of God's Judgments (London, 1597), I.25, 'Of Epicures and Atheists': 'Not inferior to any of the former in atheism and impiety, and equal to all in manner of punishment was one of our own nation, of fresh and late memory, called Marlin [sic] ... [who] denied God and his son Christ, and not only in word blasphemed the Trinity ... The manner of his death being so terrible (for he even cursed and blasphemed to his last gasp, and together with his breath an oath flew out of his mouth) that it was not only a manifest sign of God's judgment, but also an horrible and fearful terror to all that beheld him.' Beard's judgement was echoed by Frances Meres: 'As Iodelle, a French tragical poet, beeing an epicure and an atheist, made a pitifull end: so our tragicall poet Marlowe for his Epicurisme and Atheisme had a tragical death ... stabd to death by a bawdy Servingman, a riual of his in his lewde loue.' Palladis Tamia: Wit's Treasury (London, 1598), 89.

51 Dusinberre, As You Like It, 230n.

52 A clue to the locale of Marlowe's death might be hinted at in 'the waters warpe'. Water 'warps' when it freezes in a contained space, and its expansion forces the edges outwards and upwards. The word 'bite' suggests a cove or 'bight' - a body of water enclosed on three sides by land, as in the Seine Bight at the mouth of that river. But a bight is also a sharp bend in a river - such as the great bend in the Thames which separates the Isle of Dogs from Deptford Strand, where Marlowe met his death. The words 'bite', 'sting', and 'sharpe' are all suggestive of a knife as a weapon.

53 Riggs notes, 'The question of whether or not Marlowe was a homosexual is misleading. Marlowe's contemporaries regarded sodomy as an aspect of seditious behaviour rather than a species [sic] of person. The crime of sodomy became visible in connection with other offences - blasphemy, treason, counterfeiting, sorcery - that activated the heavy hand of the law. Marlowe avoided this predicament until the final weeks of his life, when he was accused of atheism, coining and crypto-Catholicism.' Riggs, The World, 76. It is also true that during his lifetime, Marlowe's 'name was never coupled with that of a woman ... both Hero and Leander and Edward II show a clear and open interest in homosexuality'. Hopkins, Christopher Marlowe, 21. 
54 The notorious 'Baines Note' quotes Marlowe as saying, 'all they that loue not Tabacco \& Boies were fooles'. Richard Baines, 'A note containing the opinion of on[e] Christopher Marly concerning his damnable Judgment of Religion, and scorn of Godes word', British Library, London, Harley MS 6848, fols. 307-8. Orlando and RosalindGanymede are both boyish, and the actor peaking Phebe's lines was a boy.

55 Among many examples: Honan, Poet and Spy, 106 ff, 241 ff, and Riggs, The World, $319 \mathrm{ff}$.

56 Ethel Seaton, 'Marlowe, Robert Poley, and the Tippings', Review of English Studies 5 (1929), 273.

57 Agnes Latham, ed., As You Like It, The Arden Shakespeare, Series 2 (London: Methuen, 1975), 79n.

58 Jonathan Bate, Shakespeare and Ovid (Oxford: Oxford University Press, 1993), 159; Brissenden, As You Like It, 174n; Dusinberre, As You Like It, 266n.

59 As You Like It contains a number of well-documented nods to Ovid; Knowles' Variorum edition cites those to Ovid himself (7) and to his Ex Ponto (1), Metamorphoses (14), and Tristia (4). Hopkins believes 'Marlowe deliberately constructed his poetic career in opposition to the accepted model, patterning himself on the subversive and licentious Roman poet Ovid rather than Ovid's more pious and civic-minded contemporary, Virgil.' Hopkins, Christopher Marlowe, 46.

60 Among other winks at Marlowe in 4.1, Hopkins sees Rosalind's 'The poor world is almost six thousand years old' (85-6) as an echo of the 'Baines Note': 'That the Indians, and many authors of antiquity, have assuredly written of above 16 thousand years agone, whereas Adam is proved [by the Bible] to have lived within six thousand years.' Hopkins, Christopher Marlowe, 17.

61 Righter, Idea, 139.

62 Affected melancholy had recently been skewered in Ben Jonson's Every Man in His Humor, perhaps performed at the Curtain in 1598 by the Lord Chamberlain's Men with Shakespeare in the part of Kno'well.

63 'Note containing the opinion of one Christopher Marly [sic] concerning his damnable judgment of religion, and scorn of God's word.' Baines, 'A note', fols. 185-6. Among Marlowe's 'monstrous opinions' attributed by Baines: 'religion was only to keep men in awe'; 'Christ was a bastard and his mother dishonest', etc.

64 'The Scythians ... take some of this hemp-seed, and, creeping under the felt coverings, throw it upon the red-hot stones; immediately it smokes, and gives out such a vapour as no Grecian vapour-bath can exceed; the Scyths, delighted, shout for joy.' George Rawlinson, ed. and trans., The History of Herodotus, 9 vols (New York: D. Appleton, 1885), V.74-5. 
65 The terms of the scholarship required 'at first sight to solf and sing plainsong' and 'if it may be, such as can make a verse'. Riggs, The World, 36.

66 Shapiro, A Year, 46-7.

67 Baldwin believes Burbage played Orlando while Shakespeare took the role of Old Adam, John Heminges that of Duke Senior, and Thomas Pope that of Jaques. T. W. Baldwin, The Organization and Personnel of the Shakespeare Company (Princeton: Princeton University Press, 1927), 43.

68 Steve Sohmer, Shakespeare for the Wiser Sort (Manchester: Manchester University Press, 2008), 81.

69 Again, I'm indebted to Ms Medawar for calling to my attention this and other appearances of seven.

70 Margie Burns, 'Odd and Even in As You Like It', Allegorica 5.1 (1980), 119-40. And again in Maurice Hunt, 'Christian Numerology and Shakespeare's The Tragedy of King Richard the Second', Christianity and Literature 60.2 (Winter 2011), 247-75.

71 Commentators debate whether Shakespeare imagined his play set in Warwickshire or in the Ardennes forest on the French-Belgian border. Hattaway reasoned that 'Arden is a name that not only signifies a "real" habitation in Shakespeare's Warwickshire but also alludes to the topos of the "greenwood" that was veneverated in idylls and in ballads.' Hattaway, As You Like It, 9.

72 Gary Taylor, 'The Canon and Chronology of Shakespeare's Plays', in Stanley Wells, Gary Taylor, John Jowett, et al., eds, William Shakespeare: A Textual Companion, 2nd edition (New York and London: W. W. Norton, 1987), 69-144.

73 Some commentators have inferred that the part of the Clown was performed by Robert Armin, and that the name Touchstone is a glance at "his training as a goldsmith: a "touchstone" (made of quartz or jasper) was used to register the quality of gold and silver alloys'. Hattaway, As You Like It, 87. That Touchstone carries a timepiece may also be a wink at Armin's calling.

74 'From Julius Caesar we look backward at Titus. The Taming of the Shrew, Two Gentlemen of Verona, The Comedy of Errors, Richard II and III, and the Henry IV-V-VI plays - work which is largely developmental, historiographical or pure entertainment. Looking forward in the playwright's career, one finds the ruthless middle comedies, profound tragedies and, at a breathing distance, the romances. Before creating Caesar, Shakespeare created Falstaff; afterwards, he created Lear. Before creating Brutus, Shakespeare created Bolingbroke; afterwards, he created Hamlet. Before creating Cassius, Shakespeare created Beaufort; afterwards, he created Ulysses. 
And before creating Antony, Shakespeare created Juliet; afterwards, he created Cleopatra.' Having done with his histories and comedies (and Titus), the thirty-five year-old Shakespeare turned to creating socially relevant and/or metaphysical plays, some of them highly if discreetly seditious.' Steve Sohmer, Shakespeare's Mystery Play and the Opening of the Globe Theatre 1599 (Manchester: Manchester University Press, 1999), 17-18.

75 Ibid., $28 \mathrm{ff}$.

76 'Marlowe's resolve to put the first book of Lucan's Civil War into English complemented his decision to translate Ovid's Amores. Lucan was Ovid's successor in the ancient line of anti-imperial poets. Where Ovid stood for the cause of personal and erotic liberty, Lucan made the case for armed resistance to Caesar's monarchial yoke. Within the Roman tradition, Ovid's Amores and Lucan's Civil War were definitive testaments to erotic and political freedom.' Riggs, The World, 187.

77 Hattaway, As You Like It, 1.

78 In Henry $V$ the Continental 'Salic law' was the subject of the obscurantist disquisition on the title to the French crown by the Archbishop of Canterbury (1.2.178-240). The Succession of the Crown Act (royal assent 25 April 2013) allows the elder child to succeed to the throne regardless of gender.

79 Hattaway cites Leicester's Commonwealth (1584): '[the Earl of Leicester] hath taken from the tenants round about their lands, woods, pastures, and commons, to make himself parks, chases and other commodities therewith, to the subversion of many a good family, which was maintained there, before this devourer set foot in that country.' [T. Morgan?], The Copy of a Letter, Written by a Master of Art of Cambridge. Leycesters Common-wealth: Conceived, Spoken and Published with Most Earnest Protestation of All Dutifull Good Will ... Towards this Realm, Etc. Sometimes Wrongly Attributed to Robert Persons (Paris, 1584), 83.

80 The shepherds awaiting the birth of Christ in The Second Shepherds' Play (ca.1500) pass the time grousing about the Enclosures Controversy.

81 Readers who remain skeptical of a Shakespeare-Marlowe connection should consider the Oxford editors' decision to credit Marlowe as coauthor of Henry VI, parts 1, 2, and 3 (New York Times, 24 October 2016).

N.B. In 1994 the late Dennis Kaye put the riddle of 'ducdame' to me during a tutorial. It has taken me twenty years to find a solution and now, regrettably, I am unable to share it with him. 